\title{
KAJIAN TEORI HUKUM PROGRESIF TERHADAP IMPLEMENTASI PRODUK TABUNGAN PERUMAHAN RAKYAT
}

\author{
Neysa Tania, Jason Novienco, dan Dixon Sanjaya \\ Fakultas Hukum Universitas Tarumanagara \\ e-mail: neysa.205180248@stu.untar.ac.id; \\ jason.205180098@stu.untar.ac.id; \\ dixon.205180023@stu.untar.ac.id
}

\begin{abstract}
ABSTRAK
Akses perumahan yang layak merupakan kebutuhan mendasar manusia yang dilindungi oleh Pasal 28H ayat (1) UUD Tahun 1945. Permasalahannya adalah tidak setiap orang memiliki akses terhadap pembiayaan untuk memperoleh rumah. Ketimpangan kondisi tersebut utamanya dipengaruhi oleh faktor pendapatan yang tidak merata. Pemerintah telah mengeluarkan Undang-Undang Nomor 4 Tahun 2016 tentang Tabungan Perumahan yang ditindaklanjuti dengan Peraturan Pemerintah Nomor 25 Tahun 2020 tentang Penyelenggaraan Tabungan Perumahan Rakyat walaupun peraturan tersebut menimbulkan sejumlah permasalahan selama masa pandemi Covid-19 yakni besaran iuran yang memberatkan pekerja dan pengusaha serta konflik norma dan ketidaksesuaian dengan pedoman pembentukan undang-undang. Penelitian yuridis normatif dengan pendekatan sinkronisasi hukum vertikal dan horizontal ini memperoleh hasil bahwa PP Tapera yang ditetapkan di masa pandemi Covid-19 mengandung cacat formil dan materiil dalam pembentukannya khususnya terhadap asas-asas dan norma yang diatur dalam PP Tapera tersebut. Program tabungan perumahan rakyat di masa pandemi Covid-19 yang memberatkan masyarakat juga inkonsisten terhadap penerapan hukum progresif yang seharusnya mengarahkan aturan hukum untuk memenuhi kebutuhan masyarakat dan bukan sebaliknya. Penelitian ini menyarakankan agar Pemerintah perlu merevisi kebijakan serta mensosialisasikan keberadaan tabungan perumahan rakyat kepada masyarakat agar tercipta kesepahaman antara para pihak.
\end{abstract}

Kata Kunci: Hukum Progresif; Peraturan Pemerintah; Tabungan Perumahan Rakyat

\section{ABSTRACT}

Access to adequate housing is a basic human need that is protected by Article $28 \mathrm{H}$ paragraph (1) of the 1945 Constitution of the Republic of Indonesia. The problem is that not everyone has access to finance to bought a house. Inequality conditions are mainly influenced by the factor of unequal income. The government has issued Act No. 4 of 2016 and the Government Regulation No. 25 of 2020 concerning the Implementation of Public Housing Savings although this regulation caused problems during the Covid-19 Pandemic, namely the amount of contributions that burdened workers and employers as well as conflicting norms and non-compliance with the guidelines for the formation of the law. This normative juridical research with a vertical and horizontal legal synchronization approach obtained the results that the PP Tapera which was stipulated during the Covid-19 pandemic contained formal and material defects in its formation, especially regarding the principles and norms regulated in the PP Tapera. The public housing savings program during the Covid-19 pandemic which burdened the community was also inconsistent with the application of progressive law which should direct the rule of law to meet the needs of the community and not the other way around. This research suggests that the government needs to revise its policies and socialize the existence of public housing savings to the public in order to create an understanding between the parties.

Keywords: Government Regulations; Progressive Law; Public Housing Fund 


\section{PENDAHULUAN}

Kebutuhan pokok yang sangat mendasar bagi keberlangsungan hidup manusia terdiri dari kebutuhan akan sandang, pangan, dan papan. Kebutuhan akan papan dalam hal ini kebutuhan untuk memperoleh tempat tinggal atau rumah. Setiap orang memerlukan tempat tinggal atau rumah sebagai tempat untuk melindungi diri dari perubahan cuaca dan sebagai salah satu syarat atau kebutuhan mutlak manusia. Namun, dalam kenyataannya tidak seluruh masyarakat memiliki kemampuan untuk memperoleh rumah. Hal tersebut disebabkan karena tingkat pendapatan yang rendah dan tidak merata, kebijakan pemerintah yang belum terlalu memperhatikan dan mendukung perekonomian rakyat dan struktur ekonomi yang kapitalis dimana rakyat diperas keringatnya untuk kepentingan penguasa dan pengusaha sedangkan kesejahteraannya tidak terjamin.

Kesengsaraan rakyat juga semakin bertambah dengan banyaknya potongan atau iuran yang harus dikeluarkan rakyat untuk mendukung perekonomian negara seperti pajak penghasilan, iuran Badan Penyelenggara Jaminan Sosial, Badan Penyelenggara Jaminan Sosial Tenaga Kerja, Pajak kendaraan bermotor, dan sebagainya yang dilegitimasi dengan peraturan hukum yang bersifat mengikat dan memaksa masyarakat. Kondisi yang demikian menyebabkan daya beli masyarakat khususnya masyarakat berpenghasilan rendah tidak mampu membeli rumah meskipun butuh dan terpaksa memilih tinggal di tempat-tempat kumuh yang tidak selayaknya. Permasalahan ini kemudian tidak didukung oleh pemerintah untuk mengembangkan dan memberikan jenis-jenis kebijakan yang bervariatif dan progresif yang memudahkan masyarakat untuk memperoleh fasilitas pembiayaan perumahan yang memadai dan dapat terjangkau. Terdapat dikotomi paradigma terhadap perumahan, di satu sisi rumah dipandang sebagai komoditas maka pemenuhan akan kebutuhan perumahan diserahkan kepada warga negara sendiri yang memiliki kemampuan berbeda-beda untuk mengaksesnya. Di sisi lain rumah dipandang sebagai hak konstitusional warga negara maka pemerintah memiliki kewajiban untuk meletakkan program perumahan dalam penyelenggaraan negara.

Kebutuhan akan rumah juga menjadi salah satu tolak ukur kesejahteraan. Hal ini sejalan dengan alinea ke-4 Pembukaan Undang-Undang Dasar 1945 (yang selanjutnya disingkat UUD 1945) yang menyatakan bahwa "... dan membentuk suatu pemerintahan Negara Indonesia yang melindungi segenap bangsa Indonesia dan seluruh tumpah darah Indonesia, dan untuk memajukan kesejahteraan umum, mencerdaskan kehidupan bangsa, dan ikut melaksanakan ketertiban dunia yang berdasarkan kemerdekaan, perdamaian abadi, dan keadilan sosial ...".

Tujuan negara tersebut kemudian juga tercermin dalam butir kelima Sila Pancasila yaitu untuk mewujudkan keadilan sosial bagi seluruh rakyat Indonesia. Pancasila dan pembukaan UUD 1945 sebagai norma dasar negara menjiwai seluruh sendi kehidupan penyelenggaraan negara, memberi arah tentang bentuk negara, cita hukum bernegara, asasasas penyelenggaraan negara sehingga negara sebagai suatu komunitas atau organisasi memiliki tujuan yang jelas dan akan memandu menuju apa yang dicitacitakan. ${ }^{1}$ Untuk mewujudkan kesejahteraan umum tersebut diperlukan peran negara sebagaimana konsep negara hukum materiil atau negara kesejahteraan (welfare state). ${ }^{2}$

Menurut Esping Andersen, negara kesejahteraan pada dasarnya, mengacu pada "peran negara yang aktif dalam mengelola dan mengorganisasi perekonomian" yang didalamnya mencakup tanggung jawab negara untuk menjamin ketersediaan pelayanan kesejahteraan dasar dalam tingkat tertentu bagi warganya. ${ }^{3}$ Negara dalam hal ini berarti memiliki tanggung jawab untuk menyediakan kesempatan bagi masyarakat untuk memperoleh akses pada perumahan atau tempat tinggal. Keberadaan rumah selain berfungsi sebagai hunian dan aset yang menunjukan kesejahteraan seseorang juga berfungsi sebagai tempat pembentukan karakter dan kepribadian bangsa sebagai salah satu usaha membangun manusia indonesia seutuhnya, berjati diri, mandiri, dan

\footnotetext{
${ }^{1}$ Satjipto Rahardjo, dikutip dari Ahmad Redi. (2018). Hukum Pembentukan Peraturan Perundang-undangan. Jakarta: Sinar Grafika, h. 72.

${ }^{2}$ Bagir Manan. (1996). Politik Perundang-undangan Dalam Rangka Mengantisipasi Liberalisme Perekonomian. Bandar Lampung: FH UNLA, h. 9.

${ }^{3}$ Darmawan Triwibowo dan Sugeng Bahagijo. (2006). Mimpi Negara Kesejahteraan. Jakarta: Pustaka LP3S Indonesia, h. 15 .
} 
produktif. ${ }^{4}$ Mengingat pentingnya kebutuhan akan rumah, lembaga Perserikatan Bangsa-Bangsa (PBB) mencantumkan hak akan rumah sebagai Hak Asasi Manusia sebagaimana dimuat dalam Resolusi 217A Deklarasi Universal Hak-Hak Asasi Manusia tanggal 10 Desember 1948 khususnya pada Pasal 25 ayat (1). ${ }^{5}$ Selain itu perlindungan hak atas rumah sebagai hak asasi juga diatur dalam sejumlah peraturan perundang-undangan di Indonesia, diantaranya: (1) Pasal 28H ayat (1) UUD 1945; (2) Pasal 40 Undang-Undang Nomor 39 Tahun 1999 tentang Hak Asasi Manusia, bahwa "setiap orang berhak untuk bertempat tinggal serta berkehidupan yang layak"; (3) Article 11 Paragraph (1) International Convenant on Economic, Social, and Cultural Rights yang telah diratifikasi dengan Undang-Undang Nomor 11 Tahun 2005 tentang Pengesahan International Convenant on Economic, Social, and Cultural Rights; dan (4) Article 26 International Convenant on Civil and Political Rights yang diratifikasi dengan UndangUndang Nomor 12 Tahun 2005 tentang Pengesahan International Convenant on Civil and Political Right.

Berdasarkan ketentuan peraturan perundangundangan tersebut, pemenuhan akan kebutuhan tempat tinggal atau rumah tidak bisa hanya diserahkan kepada masyarakat melainkan negara juga bertanggungjawab untuk menjamin terpenuhinya hak masyarakat atas perumahan ini. Pada tahun 2019, wilayah kawasan permukiman kumuh seluas 87.000 hektar, ${ }^{6}$ dimana jumlah ini meningkat lebih dari 2 (dua) kali lipat dari tahun 2014 seluas 37.407 hektar yang tersebar di 3.286 kawasan. ${ }^{7}$ Kondisi ini tentu masih jauh dari tujuan negara untuk menciptakan tempat tinggal yang layak, baik, dan sehat. Salah satu penyebab banyaknya permukiman kumuh

\footnotetext{
${ }^{4}$ Adang Sutara. "Tabungan Perumahan Rakyat (TAPERA)". Makalah disampaikan dalam Seri Webinar PERKIM ke-10. 23 Juli 2020, h. 5

${ }^{5}$ Budi Prayitno, dkk. (2012). Kesejahteraan Rakyat Atas Papan: Akselerasi Pemenuhan Papan Bagi Peningkatan Kesejahteraan Rakyat. Jakarta: Kementerian Koordinator Bidang Kesejahteraan Rakyat Republik Indonesia, h. 13

${ }^{6}$ Adhi Wicaksono. "Kawasan Kumuh Indonesia Meluas Dua Kali Lipat". Dalam CNN Indonesia. 4 September 2019. https:// www.cnnindonesia.com/nasional/20190903212554-20-427289/ kawasan-kumuh-indon esia-meluas-dua-kali-lipat. Diakses pada 22 Februari 2021.

${ }^{7}$ Direktorat Jenderal Cipta Karya Kementerian Pekerjaan Umum dan Perumahan Rakyat. "Lembaran Baru Penuntasan Kawasan Permukiman Kumuh”. Buletin Cipta Karya. Edisi 12. Tahun XII. Desember 2014, h. 8.
}

dipengaruhi kemampuan untuk mencapai akses perumahan yang sangat minim karena sebagian masyarakat Indonesia memiliki pendapatan rendah dan menengah ditambah lagi terbatasnya akses ke sistem pembiayaan perumahan. Disinilah peran pemerintah untuk mendorong peningkatan daya beli masyarakat akan perumahan dan memfasilitasi akses masyarakat untuk memperoleh sumber pembiayaan perumahan yang diseimbangkan dengan penyediaan rumah dengan harga terjangkau. Untuk membantu masyarakat mengakses perumahan, pemerintah menyelenggarakan program tabungan perumahan dengan diundangkannya UndangUndang Nomor 1 Tahun 2011 tentang Perumahan dan Kawasan Permukiman (selanjutnya disingkat UU 1 Tahun 2011). Pada Pasal 123 ayat (1) huruf b, bahwa pengerahan dan pemupukan dana untuk pengembangan sistem pembiayaan perumahan dan kawasan permukiman meliputi dana tabungan perumahan. Sedangkan pengertiannya disebutkan pada bagian penjelasan bahwa yang dimaksud dengan "tabungan perumahan ialah simpanan yang dilakukan secara periodik dalam jangka waktu tertentu, yang penarikannya hanya dapat dilakukan menurut syarat tertentu yang disepakati sesuai dengan perjanjian, dan digunakan untuk mendapatkan akses kredit atau pembiayaan untuk pembangunan dan perbaikan rumah, serta pemilikan rumah dari lembaga keuangan".

Pelaksanaan tabungan perumahan tersebut diatur lebih lanjut dalam undang-undang sebagaimana dimaksud dalam Pasal 124 UU 1 Tahun 2011. Atas perintah pasal tersebut pemerintah menerbitkan Undang-Undang Nomor 4 Tahun 2016 tentang Tabungan Perumahan Rakyat (UU Tapera) yang diundangkan tanggal 24 Maret 2016 sedangkan peraturan pelaksana UU Tapera diatur dengan Peraturan Pemerintah Nomor 25 Tahun 2020 (PP Tapera) pada tanggal 20 Mei 2020. Pada tahap pembentukan peraturan mengenai Tabungan Perumahan Rakyat (Tapera), pemerintah telah mengabaikan ketentuan perundang-undangan dimana pada UU 1 Tahun 2011 disebutkan peraturan pelaksana (termasuk UU Tapera) ditetapkan paling lambat 1 (satu) tahun setelah diundangkan. UU Tapera baru diundangkan tahun 2016, yaitu 6 tahun setelah diperintahkan. Kemudian dalam Pasal 81 UU Tapera memerintahkan bahwa peraturan pelaksana 
(termasuk PP Tapera) ditetapkan paling lama 2 (dua) tahun sejak diundangkan. Tetapi PP Tapera baru diundangkan tahun 2020, 4 tahun kemudian setelah UU Tapera memerintahkan. Pembentukan regulasi tersebut dinilai tidak taat asas pembentukan peraturan perundangan-undangan khususnya asas dapat dilaksanakan, ${ }^{8}$ asas keterbukaan, dan asas kedayagunaan dan kehasilgunaan. Secara substansial PP Tapera yang diterbitkan sebagai peraturan pelaksana dari UU Tapera masih memiliki beberapa permasalahan diantaranya beberapa pihak menilai besaran iuran Tapera akan membebankan masyarakat karena menambah beban iuran yang harus ditanggung disamping iuran BPJS dan potongan pajak penghasilan, kebijakan yang berpotensi tumpang tindih dengan kebijakan BPJS Ketenagakerjaan terkait pembiayaan perumahan, keikutsertaan Warga Negara Asing sebagai peserta Tapera, serta kedudukan, wewenang, fungsi, dan tanggung jawab Badan Pengelola Tapera terhadap dana Tapera yang dihimpun dari peserta. ${ }^{9}$ Selain itu penerbitan PP Tapera di masa pandemi Corona Virus Disease 2019 (Covid-19) akan memberatkan masyarakat dan pengusaha. Disaat pandemi Covid-19 ini banyak pengusaha mempertahankan kelangsungan usahanya dengan melakukan pengurangan gaji, perumahan karyawan hingga pemberhentian hubungan kerja. Bagi masyarakat pemberlakuan PP Tapera akan semakin memberatkan beban keuangan yang sedang sulit akibat pandemi Covid-19. Tercatat sejak pandemi Covid-19 ini setidaknya 1.757 .464 pekerja formal dan informal yang dirumahkan dan di PHK. ${ }^{10}$ Ketergantungan terhadap bantuan sosial untuk menyokong kebutuhan masyarakat masih cukup tinggi. Oleh karena itu, penerbitan PP Tapera sebagai instrumen pelaksana UU Tapera di masa Covid-19 ini menimbulkan reaksi keras dari pengusaha maupun serikat buruh yang menilai pemerintah

\footnotetext{
${ }^{8}$ Pasal 5 huruf d dan penjelasannya Undang-Undang Nomor 12 Tahun 2011 tentang Pembentukan Peraturan Perundangundangan.

${ }^{9}$ Sholihah Imas. (2016). "Polemik Undang-Undang Nomor 4 Tahun 2016 tentang Tabungan Perumahan Rakyat (TAPERA)”. Jurnal Rechts Vinding Online. Media Pembinaan Hukum Nasional. ISSN 2089-9009, h. 2.

${ }^{10} \mathrm{CNN}$ Indonesia. "Pekerja Dirumahkan dan Kena PHK Akibat Corona Capai 3,05 Juta". https://www.cnnindonesia.com/ ekonomi/20200720114203-92-526610/pekerja-dirumahkandan-kena-phk-akibat-corona-capai-305-juta. Diakses pada 23 Februari 2021.
}

tidak memiliki sumber alternatif pembiayaan untuk anggaran Covid-19 dan terkesan panik dan tidak memperhatikan kepentingan rakyat dalam penerbitan PP Tapera ini sehingga muncul ketidaktaatan bahkan kecaman terhadap pemerintah karena menerbitkan suatu program yang baik tetapi di masa yang kurang tepat. Salah satu unsur yang mempengaruhi ketaatan hukum adalah adanya relevansi antara kebutuhan hukum dengan orang yang menjadi target hukum. pembuat undang-undang dan peraturan lainnya dituntut untuk mampu memahami kebutuhan hukum dari target pemberlakuan peraturan tersebut. ${ }^{11}$ Selain itu menurut Soerjono Soekanto, penentu efektivitas hukum yang berkaitan dengan undang-undang adalah bahwa peraturan yang ada sudah cukup sinkron secara hierarki tidak ada pertentangan. ${ }^{12}$

Permasalahan tersebut menarik untuk diuji dari perspektif hukum progresif. Teori hukum progresif yang dikemukakan oleh Begawan sosiologi hukum, Satjipto Rahardjo menyatakan bahwa hukum progresif adalah hukum untuk manusia dan bukan manusia untuk hukum. Hukum progresif menempatkan humanisme sebagai progresivitas hukum progresif yang selalu didasari pada dasardasar kemanusiaan. ${ }^{13}$ Menurut Satjipto, perilaku lebih penting dalam berhukum dibanding dengan peraturan yang tidak lain adalah teks yang tidak dapat sepenuhnya merepresentasikan kehidupan hukum yang otentik. ${ }^{14}$ Hukum progresif bertujuan mengantarkan manusia kepada kesejahteraan dan kebahagiaan. Hukum harus memiliki tujuan lebih jauh dari pada yang diajukan oleh falsafah liberal. Pada falsafah pasca liberal, hukum harus menyejahterakan dan membahagiakan. ${ }^{15}$

${ }^{11}$ C.G. Howard \& R.S. Mumners. (2010). Law: Its Nature And Limits. dalam Achmad Ali. Menguak Teori Hukum (Legal Theory) \& Teori Peradilan (Judicialprudence) Termasuk Undang-Undang (Legisprudence): Volume I Pemahaman Awal. Jakarta: Kencana Prenada Media Group, h. 376.

12 Soerjono Soekanto. (2008). Faktor-Faktor Yang Mempengaruhi Penegakan Hukum. Jakarta: PT Raja Grafindo Persada, h. 80.

${ }^{13}$ Satjipto Rahardjo. (2009). Hukum Progresif: Sebuah Sintesa Hukum Indonesia. Yogyakarta: Genta Publishing, h. 17.

${ }^{14}$ Satjipto Rahardjo. (2009). Hukum dan Perilaku. Jakarta: Kompas, h. 20.

${ }^{15}$ Sidharta. Satjipto Raharjo dan Hukum Progresif Urgensi dan Kritik, dalam Any Farida. (2016). "Teori Hukum Pancasila Sebagai Sintesa Konvergensi Teori-Teori Hukum Indonesia”. Jurnal Perspektif. XXI (1), h. 65. 
Hukum menurutnya tidak hanya sekedar teks. Skema hukum yang menempatkan perilaku manusia menjadi sebatas teks-teks hukum membuat hukum menjadi stagnan, keras dan kaku (lex dura sed tamen scripta). Hal tersebut merupakan salah satu sebab, mengapa hukum modern mengalami kegagalan serius. Karena itu hukum mesti dikembalikan secara "progresif " kepada perilaku. ${ }^{16}$ Meskipun perilaku berada di atas peraturan-peraturan, bukan berarti peraturan hukum positif tidak diperlukan sama sekali. Norma hukum positif ternyata tetap diperlukan, dan Satjipto Rahardjo tidak menolak atau menyangkal adanya hukum positif. ${ }^{17}$ Hukum positif yang harus mampu memahami kebutuhan hukum dari target pemberlakuan suatu peraturan dan peraturan hanya dapat berlaku efektif apabila dipatuhi oleh masyarakatnya. Menurut J.J. Bruggink, terdapat 3 (tiga) bentuk keberlakuan hukum, yaitu: ${ }^{18}$

Pertama, Keberlakuan faktual atau empiris, yaitu perilaku sebenarnya dari masyarakat termasuk aparat penegak hukum mematuhi, menegakkan, dan menerapkan suatu hukum atau tidak;

Kedua, Keberlakuan secara normatif atau formal, yaitu keberlakuan hukum yang didasarkan pada eksistensi peraturan dalam sistem aturan atau hierarki peraturan perundang-undangan;

Ketiga, Keberlakuan secara evaluatif, yaitu keberlakuan hukum dilihat dari segi isinya, dipandang benar, bernilai, atau penting terhadap perilaku sosial masyarakat.

Soerjono Soekanto juga mengemukakan 3 (tiga) hal yang mempengaruhi berlakunya hukum yang dikenal dengan istilah Gelding Theory, diantaranya: ${ }^{19}$

(1) kaidah hukum tersebut berlaku secara yuridis; (2) kaidah hukum itu berlaku secara sosiologis yang diterima oleh masyarakat secara umum dan berlaku secara efektif; dan (3) kaidah hukum itu berlaku secara filosofis yang berarti sesuai dengan cita-cita hukum sebagai nilai positif yang tertinggi.

\footnotetext{
${ }^{16}$ Satjipto Rahardjo. (2010). Penegakan Hukum Progresif. Jakarta: Kompas, h. 13- 21.

${ }^{17}$ Hyronimus Rhiti. (2016). "Landasan Filosofis Hukum Progresif”. Jurnal Justitia Et Pax. 32 (1), h. 37.

18 J.J. H. Bruggink diterjemahkan oleh Arief Sidharta (1999). Refleksi tentang Hukum. Bandung: Citra Aditya Bakti, h. 147.

${ }^{19}$ Soerjono Soekanto. (1983). Penegakan Hukum. Bandung: Bina Cipta, h. 29.
}

Berdasarkan latar belakang tersebut perlu dikaji penerbitan PP Tapera benar-benar ditujukan untuk kemanfaatan bagi rakyat mengingat di masa pandemi Covid-19 ini hampir seluruh masyarakat, bangsa, dan negara mengalami kesulitan.

\section{RUMUSAN MASALAH}

Berdasarkan latar belakang yang telah diuraikan, maka terdapat beberapa permasalahan yang dikemukakan, yaitu hakikat pembentukan PP Tapera berdasarkan UU 12 Tahun 2011 tentang Pembentukan Peraturan Perundang-undangan, dan penerapan PP Tapera di tengah pandemi Covid-19 apabila ditinjau dari teori hukum progresif.

\section{METODE PENELITIAN}

Metode penelitian dapat dimaknai sebagai suatu pendekatan umum ke arah fenomena yang telah dipilih untuk diselidiki secara komprehensif. ${ }^{20}$ Dengan demikian dapat diartikan bahwa metode penelitian merupakan sejenis logika yang mengarahkan penelitian. Penelitian yang dilakukan merupakan penelitian hukum yaitu suatu kegiatan ilmiah yang didasarkan pada metode, sistematika, dan pemikiran tertentu yang memiliki tujuan untuk mempelajari satu atau beberapa gejala hukum tertentu. ${ }^{21}$

Penelitian hukum ini dilihat dari sumber datanya merupakan penelitian hukum normatif yaitu penelitian yang ditujukan untuk menemukan dan merumuskan argumentasi hukum melalui analisis terhadap pokok permasalahan. ${ }^{22}$ Penelitian dilakukan dengan mengkaji norma, kaidah, dan asas hukum yang berlaku. ${ }^{23}$ Penelitian hukum normatif juga diartikan sebagai penelitian yang meletakkan hukum sebagai bangunan sistem norma yang berkaitan dengan asas, norma, dan kaidah dari peraturan perundang-undangan, putusan pengadilan, perjanjian, serta doktrin/ajaran para

\footnotetext{
${ }^{20}$ Supriyadi. (2015). "Penetapan Tindak Pidana Sebagai Kejahatan dan Pelanggaran Dalam Undang-Undang Pidana Khusus”. Jurnal Mimbar 27 (3), h. 392.

${ }^{21}$ Soerjono Soekanto. (2007). Pengantar Penelitian Hukum. Jakarta: UI PRESS, h. 43.

${ }^{22}$ Philipus M. Hardjon dan Tatiek Sri Djamiati. (2020). Argumentasi Hukum. Cet. Ke-4. Yogyakarta: UGM Press, h. 3.

${ }^{23}$ Roni Hanitijo Soemitro. (1994). Metode Penelitian Hukum dan Jurimetri. Jakarta: Ghalia Indonesia, h. 10.
} 
ahli. ${ }^{24}$ Penelitian hukum normatif dapat mencakup penelitian terhadap asas hukum, sistematika hukum, penelitian terhadap sinkronisasi hukum vertikal dan horizontal, perbandingan hukum, atau sejarah hukum. ${ }^{25}$ Dalam penelitian ini yang dikaji terkait dengan asas-asas hukum dan sinkronisasi hukum secara vertikal dan horizontal. Penelitian terhadap asas-asas hukum dilakukan dengan cara mengadakan identifikasi terhadap kaidah-kaidah hukum yang telah dirumuskan dalam peraturan perundangundangan kemudian ditarik asas-asas hukumnya. ${ }^{26}$ Sedangkan penelitian terhadap taraf sinkronisasi hukum secara vertikal dan horizontal meneliti sejauh mana hukum positif tertulis yang ada harmonis dan tidak bertentangan, baik dengan peraturan perundang-undangan yang hierarkis maupun peraturan perundang-undangan yang sederajat terhadap bidang yang sama. ${ }^{27}$ Jenis penelitian yang digunakan apabila dilihat dari bentuknya merupakan penelitian preskriptif. Penelitian preskriptif bertujuan untuk memberikan gambaran atau merumuskan masalah sesuai dengan keadaan atau fakta yang ada. Dengan kata lain penelitian preskriptif bertujuan untuk mendapatkan saran-saran mengenai apa yang harus dilakukan untuk mengatasi masalah tersebut. ${ }^{28}$ Analisis bahan hukum dalam penelitian ini dilakukan secara kualitatif.

Bahan penelitian yang digunakan merupakan bahan hukum sekunder yaitu bahan hukum yang bersumber dari bahan-bahan kepustakaan yang bersifat tertulis yang dikumpulkan dengan penelitian kepustakaan (library research) dengan studi dokumen yang tersedia. Bahan hukum sekunder dibedakan menjadi bahan hukum primer, bahan hukum sekunder, dan bahan hukum tersier. ${ }^{29}$ Bahan hukum primer yaitu bahan hukum yang memiliki sifat otoritatif atau mengikat seperti UUD 1945,

${ }^{24}$ Mukti Fajar dan Yulianto Achmad. (2017). Dualisme Penelitian Hukum Normatif dan Empiris. Cetakan IV. Yogyakarta: Pustaka Pelajar, h. 33.

${ }^{25}$ Soerjono Soekanto dan Sri Mamudji. (2001). Penelitian Hukum Normatif Suatu Tinjauan Singkat. Jakarta: Rajawali Press, h. 14.

${ }^{26}$ ibid., h. 15.

27 ibid., h. 19.

${ }^{28}$ H. Salim H.S. dan Erlies Septiana Nurbani. (2013). Penerapan Teori Hukum Pada Penelitian Tesis dan Disertasi. Jakarta: Raja Grafindo, h. 9.

${ }^{29}$ Soerjono Soekanto dan Sri Mamudji. op.cit., h. 12.
Undang-Undang Nomor 12 Tahun 2011 tentang Pembentukan Peraturan Perundang-undangan dan Perubahannya, UU Tapera, dan PP Tapera, dan peraturan terkait lainnya. Bahan hukum sekunder memberikan penjelasan atas bahan hukum primer yang bersumber dari rancangan undang-undangan, hasil penelitian, hasil karya kalangan hukum dan lainnya. Bahan hukum tersier yaitu bahan-bahan yang digunakan untuk mendukung, menjelaskan, dan memberi petunjuk atas bahan primer dan sekunder dalam mengkaji suatu gejala atau isu hukum yang dihadapi.

\section{PEMBAHASAN}

Pembentukan PP Tapera Berdasarkan UndangUndang Nomor 12 Tahun 2011 tentang Pembentukan Peraturan Perundang-undangan

Dalam Pembukaan (Preambule) UUD 1945, dinyatakan bahwa negara berkewajiban melindungi segenap bangsa Indonesia. Salah satu bentuk perlindungan yang dimaksudkan sesuai dengan ketentuan Pasal 28H ayat (1) UUD 1945 adalah hak setiap orang untuk hidup sejahtera lahir dan batin, bertempat tinggal, dan mendapatkan lingkungan hidup yang baik dan sehat. Dimana hak untuk bertempat tinggal juga tercantumkan dalam UU HAM yang menyatakan bahwa negara harus melindungi dan menyediakan akses bagi seluruh penduduk terhadap sistem pembiayaan perumahan yang disertai dengan berbagai kemudahan untuk pembangunan dan perolehan rumah, yaitu dalam bentuk penyediaan lahan, prasarana, sarana, dan utilitas umum. keringanan biaya perizinan, bantuan stimulan dan insentif fiskal, serta kemudahan dan/ atau bantuan pembiayaan perumahan yang berupa skema pembiayaan, penjamin atau asuransi, dan/atau dana murah jangka panjang. Salah satu upaya untuk menjalankan upaya tersebut sebenarnya sudah dimulai sejak tahun 1993. Dimana pemerintah mengeluarkan Keputusan Presiden Nomor 14 Tahun 1993 tentang Tabungan Perumahan Pegawai Negeri Sipil. Kemudian, pada tahun 2004, Pemerintah membentuk kembali Undang-Undang Nomor 40 Tahun 2004 tentang Sistem Jaminan Nasional meskipun dalam regulasi tersebut, jaminan akan kebutuhan perumahan tidak dijelaskan secara spesifik, dan selanjutnya pada tahun 2011, Pemerintah menerbitkan UndangUndang Nomor 1 Tahun 2011 tentang Perumahan 
dan Kawasan Permukiman, Undang-Undang Nomor 20 Tahun 2011 tentang Rumah Susun, dan pada tahun 2016, Pemerintah menerbitkan UU Tapera.

Konteks pembangunan perumahan dan permukiman yang secara tersirat terdapat dalam Pasal 28H ayat (1) UUD NRI 1945 dan UndangUndang Nomor 39 Tahun 1999 tentang Hak Asasi Manusia kemudian dipertegas kembali pada UndangUndang Nomor 1 Tahun 2011 tentang Perumahan dan Kawasan Permukiman yang menyebutkan bahwa perumahan adalah kumpulan rumah sebagai bagian dari permukiman, baik perkotaan maupun perdesaan, yang dilengkapi dengan prasarana, sarana, dan fasilitas umum tersebut diantaranya meliputi penyediaan air minum, pembuangan sampah, tersedianya listrik, telepon, jalan, dan infrastruktur lainnya. Untuk itu, Pemerintah merumuskan strategi dan arah tujuan pembangunan perumahan dan permukiman sesuai dengan yang tercantum dalam Rencana Pembangunan Jangka Menengah Nasional (RPJM) serta untuk memenuhi Tujuan Pembangunan Berkelanjutan atau Sustainable Development Goals (SDGs). Namun karena upaya untuk memenuhi kebutuhan akan tempat tinggal yang layak masih dihadapkan pada kondisi permasalahan keterjangkauan, aksesibilitas, serta ketersediaan dana dan dana murah jangka panjang untuk menunjang pembiayaan perumahan, negara bertanggung jawab menyelenggarakan tabungan perumahan sebagai sistem pembiayaan perumahan tersebut, yang terdapat di Penjelasan Umum UU Tapera. ${ }^{30}$ Pola penghimpunan dana seperti program Tapera sebenarnya sudah lazim dilakukan di berbagai negara. Misalnya di Singapura terdapat CPF (Central Provident Fund), di Malaysia ada Employees Provident Fund (EPF) atau yang disebut dengan KWSP (Kumpulan Wang Simpanan Pekerja), di Korea Selatan terdapat NHUF (National Housing and Urban Fund) yang terintegrasi dalam sistem jaminan sosial nasional pada negara masing-masing. Dengan UU Tapera merupakan upaya pemerintah untuk menjamin kebutuhan dasar (basic need) masyarakat dalam rangka pemenuhan hak-hak mereka untuk mendapatkan perumahan. Namun, sejak UU Tapera itu disahkan pada tanggal 23 Februari 2016, hal tersebut telah menuai banyak polemik, baik dari segi formil maupun materiil dari kaum masyarakat.

\footnotetext{
${ }^{30}$ Penjelasan Umum UU Tapera.
}

Dari sisi formil dan materiil perundangundangan, Indonesia mengenal adanya UndangUndang Nomor 12 Tahun 2011 tentang Pembentukan Peraturan Perundang-undangan. Jika kita merujuk kepada Teori Jenjang Hukum (theorie von stufenbau der rechtsordnung) yang dikembangkan oleh Hans Kelsen yang kemudian disempurnakan oleh Hans Nawiasky, tataran UUD 1945 merupakan tingkatan Aturan Pokok Negara (Staatsgrundgesetz) yang masih berupa aturan-aturan pokok bernegara. Kemudian, dibawahnya terdapat Undang-undang Formal (Formell Gesetz) yang menjadi dasar aturan Pelaksana (Verordnung \& Autonome Satzung). ${ }^{31}$ Teori Hans Kelsen dan Hans Nawiasky ini mengilhami adanya pengaturan norma hukum berdasarkan Hierarki di dalam hukum Indonesia. Teori Hierarki merupakan teori yang menyatakan bahwa sistem hukum merupakan sistem anak tangga dengan kaidah berjenjang. Seperti yang diungkapkan Hans Kelsen dalam bukunya General Theory of Law and State, "The unity of these norms is constituted by the fact that the creation of one norm - the lower one - is determined by another - the higher - the creation of which is determined by a still higher norm, and that this regressus is terminated by a highest, the basic norm which, being the supreme reason of validity of the whole legal order, constitutes its unity". ${ }^{32}$ Maka dari itu, norma hukum yang rendah harus berpegangan dengan norma hukum yang lebih tinggi. Hal tersebut sesuai dengan Pasal 7 ayat (1) UU Nomor 12 Tahun 2011 yang mengamini adanya "jenis dan hierarki peraturan perundang undangan yang terdiri atas: a. Undang-Undang Dasar Negara Republik Indonesia Tahun 1945; b. Ketetapan Majelis Permusyawaratan Rakyat; c. Undang-Undang/Peraturan Pemerintah Pengganti Undang-Undang; d. Peraturan Pemerintah; e. Peraturan Presiden; f. Peraturan Daerah Provinsi; dan g. Peraturan Daerah Kabupaten/Kota."

Oleh karena itu, PP Tapera yang hierarkinya berada di bawah UU Tapera merupakan peraturan pelaksana dari undang-undang tersebut. Adanya sebuah peraturan pelaksana merupakan suatu fungsi untuk melaksanakan perintah atau delegasi

${ }^{31}$ Hans Nawiasky. (1941). Allgemeine Rechtslehre Als System Der Rechtlichen Grundbegriffe. Einsiedeln Etc: Benziger, h. 31 .

${ }^{32}$ Hans Kelsen, diterjemahkan oleh Anders Wedberg. (2011). General Theory of Law and State. Clark, N.J.: The Lawbook Exchange, h. 124. 
dari peraturan di atasnya yang mendelegasikannya. Pembentukan PP Tapera merupakan pelaksanaan dari ketentuan Pasal 16, Pasal 17 ayat (2), Pasal 21 ayat (5), Pasal 35 ayat (3), Pasal 62 ayat (3) dan Pasal 72 ayat (2) UU Tapera.

Pembentukan Tapera merujuk pada Pasal 2 UU Tapera mendasarkan bahwa "Tapera ini dikelola dengan berasaskan: a. kegotongroyongan; b. kemanfaatan; c. nirlaba; d. kehati-hatian; e. keterjangkauan dan kemudahan; f. kemandirian; g. keadilan; h. keberlanjutan; i. akuntabilitas; j. keterbukaan; k. portabilitas; dan 1. dana amanat."

Secara materiil, asas dalam Pasal 2 UU Tapera ini telah sesuai dengan asas pembentukan peraturan perundang-undangan yang baik yang terurai dalam Pasal 5 Undang-Undang Nomor 12 Tahun 2011 yang menyatakan bahwa "Dalam membentuk Peraturan Perundang-undangan harus dilakukan berdasarkan pada asas Pembentukan Peraturan Perundangundangan yang baik yang meliputi: a. kejelasan tujuan; b. kelembagaan atau pejabat pembentuk yang tepat; c. kesesuaian antara jenis, hierarki, dan materi muatan; d. dapat dilaksanakan; e. kedayagunaan dan kehasilgunaan; f. kejelasan rumusan; dan g. keterbukaan."

Namun, apabila kita melihat fakta yang ada di lapangan, kebijakan yang terdapat dalam UU Tapera ini belum sepenuhnya mengakomodir asasasas tersebut. Jika kita melihat pada Pasal 79 pada bab Ketentuan Penutup pada UU Tapera yang menyatakan bahwa: "Peraturan pelaksanaan dari Undang-Undang ini harus telah ditetapkan paling lama 2 (dua) tahun terhitung sejak Undang-Undang ini diundangkan." Jika kita menginterpretasikan pasal tersebut dengan seksama, maka yang dimaksud dengan peraturan pelaksanaan tersebut seharusnya paling lama diterbitkan paling lama pada bulan Maret 2018, yaitu paling lama 2 (dua) tahun sejak Undang-Undang tersebut diundangkan. Dalam hal ini, yang menjadi suatu kejanggalan adalah ketika Pasal 2 huruf d UU Tapera ini mendalilkan adanya asas kehati-hatian, namun nyatanya, PP Tapera ini baru dikeluarkan pada tahun 2020, 2 (dua) tahun lebih daripada yang seharusnya. Menurut Suryadi Jaya Purnama, Anggota Komisi V DPR, kebijakan Tapera melalui PP Tapera tersebut kemudian dinilai tidak tepat. Selain masih dalam pandemi Covid-19, pertumbuhan ekonomi nasional menurun signifikan. ${ }^{33}$ Mengenai hal tersebut, pemerintah menjawab bahwa pembahasan peraturan pelaksana tersebut sudah melalui proses yang panjang. ${ }^{34} \mathrm{Hal}$ tersebut memang dibenarkan oleh Suharno yang menyatakan bahwa proses pembuatan kebijakan merupakan pekerjaan yang rumit dan kompleks dan tidak semudah yang dibayangkan. Walaupun demikian, para administrator sebuah organisasi atau institusi atau lembaga dituntut memiliki tanggung jawab dan kemauan, serta kemampuan atau keahlian, sehingga dapat membuat kebijakan dengan resiko yang diharapkan (intended risks) maupun yang tidak diharapkan (unintended risks). ${ }^{35}$ Dalam menjalankan kewenangannya, Pemerintah seharusnya berdasarkan pada Undang-Undang Nomor 30 Tahun 2014 tentang Administrasi Pemerintahan yang berlandaskan pada Asas-Asas Umum Pemerintahan yang Baik (AUPB), dimana salah satu asasnya berdasarkan Pasal 10 ayat (1) huruf a adalah kepastian hukum. Tidak adanya pengaturan dan penjelasan mengenai bagaimana jika batas waktu yang diperintahkan di dalam Pasal 79 UU Nomor 4 Tahun 2016 tersebut dilanggar menimbulkan ketidakpastian hukum bagi Aparat Sipil Negara, Tentara Negara Indonesia, Polisi Rakyat Indonesia, Karyawan BUMN dan BUMD atau mereka yang penghasilannya dikutip dalam Pasal 7 UU Nomor 4 Tahun 2016. Hal tersebut tentu saja bertentangan dengan Pasal 28D ayat (1) UUD 1945 yang menyatakan bahwa "setiap orang berhak atas pengakuan, jaminan, perlindungan, dan kepastian hukum yang adil serta perlakuan yang sama di hadapan hukum" dan juga Pasal 5 huruf i UU Nomor 12 Tahun 2011 yang menyatakan bahwa setiap materi muatan peraturan perundang-undangan harus dapat mewujudkan ketertiban dalam masyarakat melalui jaminan kepastian hukum.

Permasalahan yang timbul adalah apakah PP Nomor 25 Tahun 2020 yang terbit melebihi batas waktu yang ditentukan dalam Undang-Undang

${ }^{33}$ Rofiq Hidayat. "Sejumlah Usulan Agar Pemerintah Merevisi PP Tapera.” https://www.hukumonline.com /berita/ baca/lt5ed87f8ac6144/sejumlah-usulan-agar-pemerintahmerevisi-pp-tapera. Diakses pada tanggal 17 Maret 2021.

${ }^{34}$ Ade Miranti Karunia. (16 Juni 2020). "Pemerintah Klaim Terbitnya PP Tapera Melalui Proses yang Panjang." https:// money.kompas.com/read/2020/06/16/204200126/pemerintahklaim-terbitnya-pp-tapera-melalui-proses-yang-panjang. Diakses pada tanggal 17 Maret 2021.

35 Suharno. (2010). Dasar-Dasar Kebijakan Publik. Yogyakarta: UNY Press, h. 52. 
Nomor 4 Tahun 2016 mengakibatkan konsekuensi yuridis? Hal yang serupa ternyata pernah diajukan Judicial Review terhadap Mahkamah Konstitusi dalam Permohonan Perkara Nomor 93/PUUXVIII/2020 tentang "Lewatnya Batas Waktu Penerbitan Peraturan Pelaksana Undang-Undang Nomor 2 Tahun 2017 tentang Jasa Konstruksi." Dimana nyatanya, terlambatnya suatu Peraturan Pelaksana dapat menyebabkan ketidakpastian hukum bagi masyarakat.

Selanjutnya, jika kita merujuk pada salah satu asas pembentukan peraturan perundang-undangan yang baik yang terdapat dalam pasal 5 huruf d UU Nomor 12 Tahun 2011 yaitu asas dapat dilaksanakan, jika kita merujuk pada penjelasan pasal tersebut, yang dimaksud dengan "asas dapat dilaksanakan" adalah bahwa setiap Pembentukan Peraturan Perundangundangan harus memperhitungkan efektivitas Peraturan Perundang-undangan tersebut di dalam masyarakat baik secara filosofis, sosiologis, maupun yuridis. Bahwa jika kita membicarakan tentang efektivitas hukum, Soerjono Soekanto menyatakan bahwa efektif atau tidaknya suatu hukum ditentukan oleh 5 (lima) faktor, yaitu: pertama, Faktor Hukumnya itu sendiri (Undang-Undang); kedua, Faktor penegak hukum, yakni pihak-pihak yang membentuk maupun menerapkan hukum; ketiga, Faktor sarana atau fasilitas yang mendukung penegakan hukum; keempat, Faktor masyarakat, yakni lingkungan dimana hukum tersebut berlaku dan diterapkan; dan kelima, Faktor kebudayaan, yakni sebagai hasil karya, cipta, dan rasa yang didasarkan pada karsa manusia di pergaulan hidup. ${ }^{36}$

Bahwa salah satu faktor efektif atau tidaknya sebuah hukum dilihat berdasarkan faktor masyarakat dimana lingkungan hukum tersebut berlaku dan diterapkan. Di tengah situasi perekonomian, sosial dan kesehatan yang tidak stabil, rasanya penerapan asas kedayagunaan dan kehasilgunaan yang menyatakan bahwa setiap Peraturan Perundangundangan dibuat karena memang benar-benar dibutuhkan dan bermanfaat dalam mengatur kehidupan bermasyarakat, berbangsa, dan bernegara dalam Pasal 5 huruf e UU Nomor 12 Tahun 2011 belum dapat diterapkan dengan baik.

Tapera merupakan perangkat untuk mengelola dana masyarakat secara bersama-sama dan saling

\footnotetext{
${ }^{36}$ Soerjono Soekanto. op.cit., h. 8.
}

menolong antar peserta dalam menyediakan dana murah jangka panjang dalam rangka memenuhi kebutuhan perumahan yang layak dan terjangkau bagi Peserta. Tapera juga merupakan stimulus yang positif dalam skema pembiayaan perumahan. Namun dalam pembentukan peraturan pelaksananya, Dimana dalam hal ini, merupakan PP Tapera belum sepenuhnya sesuai dengan UU Nomor 12 Tahun 2011. Oleh karena itu, dibutuhkan peran pemerintah untuk dapat menyesuaikan peraturan pelaksana tersebut dengan tetap memperhatikan hak konstitusional dan hak asasi masyarakat.

\section{Penerapan PP Tapera di Tengah Pandemi Covid-19 Dalam Perspektif Teori Hukum Progresif}

Penetapan PP Tapera pada masa pandemi Covid-19 dinilai tidak sensitif terhadap kondisi sosial yang terjadi dalam kehidupan masyarakat pada saat ini. Pemerintah juga menyatakan bahwa pandemi Covid-19 berdampak terhadap segala aspek dan bidang kehidupan masyarakat, khususnya aspek ekonomi. Sejak terjadinya pandemi Covid-19, perekonomian global termasuk Indonesia mengalami ketidakpastian dan mengarah pada resesi ekonomi karena masyarakat harus membatasi ruang geraknya sehingga pemerintah memberlakukan kebijakan Work from Home (WFH), Pembatasan Sosial Berskala Besar (PSBB) dan karantina wilayah agar dapat menekan jumlah penyebaran wabah Covid-19. Sehingga banyak usaha-usaha kecil masyarakat yang harus tutup untuk sementara waktu dan kinerja perseroan-perseroan besar juga mengalami penurunan bahkan hingga terjadi Pemutusan Hubungan Kerja (PHK) oleh beberapa perusahaan karena pandemi Covid-19. Badan Pusat Statistik telah mencatat laju pertumbuhan ekonomi Indonesia pada Kuartal I (Januari-Maret) 2020 hanya tumbuh 2,97\%. Angka ini melambat dari 4,97\% pada Kuartal IV 2019. Bahkan, pertumbuhan jauh di bawah pencapaian Kuartal I 2019 yang mencapai 5,07\%. Dan pada Kuartal II Tahun 2020 laju pertumbuhan ekonomi Indonesia minus 5,32\%. Angka itu berbanding terbalik dengan Kuartal II Tahun 2019 sebesar 5,05\%. ${ }^{37}$

${ }^{37}$ Dewi Wuryandani. (2020). "Dampak Pandemi Covid-19 Terhadap Pertumbuhan Ekonomi Indonesia 2020 dan Solusinya". Info Singkat Bidang Ekonomi dan Kebijakan Publik. XII (15), h. 19-20. 
Di tengah situasi perekonomian, sosial dan kesehatan yang tidak stabil, tepat pada tanggal 20 Mei 2020 Pemerintah menerbitkan PP Tapera sebagai peraturan pelaksana dari UU Tapera Nomor 4 Tahun 2016. Pasal 3 UU Tapera ini bertujuan untuk menghimpun dan menyediakan dana murah jangka panjang yang berkelanjutan untuk pembayaran perumahan dalam rangka memenuhi kebutuhan rumah yang layak dan terjangkau bagi peserta. Hal ini mewajibkan masyarakat khususnya pekerja untuk menyisihkan gaji atau upah dan penghasilannya untuk dibayarkan ke simpanan peserta tabungan perumahan masyarakat secara periodik baik itu oleh pemberi kerja dan/atau pekerja. Berdasarkan Pasal 7 UU Tapera jo. Pasal 5 PP Tapera, Peserta yang dimaksud diwajibkan kepada setiap pekerja dan pekerja mandiri yang berusia paling rendah 20 tahun, sudah kawin dan berpenghasilan paling sedikit sebesar upah minimum. Bagi pekerja dan pekerja mandiri yang berpenghasilan di bawah upah minimum juga dapat mendaftar untuk menjadi peserta tabungan perumahan rakyat. Jika ditelusuri, tabungan perumahan rakyat ini berlaku untuk setiap pekerja dan yang berprofesi dalam bidang usaha apapun tanpa terkecuali, yang berpenghasilan setidak-tidaknya upah minimum, sebagaimana dinyatakan dalam Pasal 7 PP Tapera, yang berbunyi: "Pekerja sebagaimana dimaksud dalam Pasal 5 ayat (2) huruf a meliputi: a. calon Pegawai Negeri Sipil; b. pegawai Aparatur Sipil Negara; c. prajurit Tentara Nasional Indonesia; d. prajurit siswa Tentara Nasional Indonesia; e. anggota Kepolisian Negara Republik Indonesia; f. pejabat negara; g. pekerja/buruh badan usaha milik negara/daerah; h. pekerja/buruh badan usaha milik desa; i. pekerja/buruh badan usaha milik swasta; dan j. pekerja yang tidak termasuk Pekerja sebagaimana dimaksud pada huruf a sampai dengan huruf i yang menerima Gaji atau Upah."

Masyarakat khususnya pekerja dan/atau pemberi kerja harus menyerahkan atau membayar sejumlah uang secara periodik ke simpanan peserta tabungan perumahan masyarakat. Berdasarkan Pasal 14 ayat (3) PP Tapera, besaran simpanan peserta tersebut ditetapkan berdasarkan persentase tertentu dari; (a) gaji atau upah yang dilaporkan setiap bulan untuk peserta pekerja; dan (b) penghasilan rata-rata setiap bulan dalam 1 tahun sebelumnya dengan batas tertentu untuk peserta pekerja mandiri. Besaran persentase yang dimaksud di atas dipertegas dalam Pasal 15 PP Tapera, yang menyatakan bahwa besaran simpanan peserta tabungan perumahan rakyat adalah sebesar 3\% dari gaji atau upah dan penghasilan, yang kemudian untuk pekerja dibayarkan oleh pemberi kerja sebesar $0,5 \%$ dan oleh pekerja sebesar 2,5\% sedangkan untuk pekerja mandiri ditanggung sendiri oleh pekerja mandiri. Sedangkan dasar perhitungan untuk menentukan perkalian besaran simpanan peserta bagi pekerja swasta diatur oleh menteri yang menyelenggarakan urusan di bidang ketenagakerjaan (Pasal 15 ayat (4) PP Tapera). Pemberi kerja wajib membayar simpanan peserta yang menjadi kewajibannya, dan memungut simpanan peserta yang menjadi kewajiban pekerjanya dan simpanan tersebut disetorkan paling lambat tanggal 10 bulan berikutnya dari bulan simpanan yang bersangkutan ke rekening dana Tapera (Pasal 20 PP Tapera). ${ }^{38}$

Iuran wajib sebesar 3\% inilah yang menimbulkan keresahan masyarakat khususnya pekerja dan pemberi kerja di tengah masa pandemi Covid-19. Banyak pekerja yang telah mengalami pemotongan gaji atau upah, hilangnya mata pencahariannya karena di PHK, ada juga yang tertular virus Covid-19 sehingga pekerja harus dirawat dan tidak dapat bekerja. Anggota Komisi V DPR RI Irwan Fecho juga mempertanyakan kebijakan PP Nomor 25 Tahun 2020, bukan masalah besaran persennya tetapi pelaksanaan dari PP yang harus sekarang di tengah pandemi Covid-19. Menurut beliau, saat ini rakyat sudah cukup sulit bertahan di tengah situasi ekonomi akibat pandemi, tetapi pemerintah terus mengambil uang rakyat untuk program-program yang menyangkut kepentingan rakyat. ${ }^{39}$ Pada masa perekonomian yang sulit seperti ini perusahaanperusahaan juga tengah berjuang melakukan efisiensi, perampingan anggaran dan menjaga kestabilan arus kas (cash flow) dengan cara menekan biaya pengeluaran yang tidak terlalu dibutuhkan, sehingga pengusaha merasa terbebani untuk mengeluarkan

\footnotetext{
${ }^{38}$ Novianti. (2020). "Implikasi PP Penyelenggaraan Tapera dan PP Penyelenggaraan Program JHT Terhadap Program Perumahan Bagi Pekerja Swasta". Info Singkat Bidang Hukum. XII (12), h. 2-3.

39 DPR RI, "Legislator Pertanyakan Penerbitan PP Tapera di Tengah Pandemi”. https://www.dpr.go.id/berita/detail/ id/28949/t/ Legislator + Pertanyakan + Penerbitan $+P P+$ Taper$a+d i+$ Tengah + Pandemi, Diakses tanggal 23 Februari 2021.
} 
iuran tambahan untuk pekerja dan karyawan yang menjadi peserta Tapera tersebut.

Selain itu dengan adanya PP Tapera ini, masyarakat semakin terbebani mengingat banyaknya iuran wajib yang harus dibayarkan kepada instansi pemerintah seperti iuran BPJS Ketenagakerjaan sebesar $5,7 \%$ yang sebenarnya pada program Jaminan Hari Tua (JHT) BPJS Ketenagakerjaan yang manfaatnya berupa uang tunai yang dibayarkan apabila peserta berusia 56 tahun, meninggal dunia, atau mengalami cacat total tetap (Pasal 22 ayat (1) PP Nomor 46 Tahun 2016 tentang Penyelenggaraan Program Jaminan Hari Tua). Selain itu, peserta program JHT BPJS Ketenagakerjaan juga mendapatkan Manfaat Layanan Tambahan (MLT) berupa fasilitas pembiayaan perumahan dan/atau manfaat lain. Dengan demikian adanya 2 (dua) PP tersebut menimbulkan implikasi terhadap pekerja swasta dimana beban pekerja semakin besar karena mempunyai kewajiban menjadi peserta dan membayar iuran..$^{40}$

Adapun implikasi kedua PP tersebut terkait program perumahan bagi pekerja swasta di antaranya: Pertama, terkait dengan besaran simpanan peserta dalam PP Penyelenggaraan Tapera yakni $3 \%$ dari gaji atau penghasilan pekerja. Sementara dalam PP Penyelenggaraan Program JHT, sebesar 5,7\% dari upah. Dengan demikian, implikasi PP Penyelenggaraan Tapera menimbulkan beban bagi pekerja maupun pemberi kerja karena adanya penambahan iuran. Kedua, terkait program perumahan pemanfaatan dana Tapera juga diatur dalam fasilitas perumahan melalui MLT JHT dalam PP Penyelenggaraan Program JHT. Hal ini menimbulkan duplikasi karena skema pembiayaan perumahan dalam PP Penyelenggaraan Tapera meliputi skema pembiayaan untuk pemilikan rumah, pembangunan rumah, atau perbaikan atau renovasi rumah. Skema atau program tersebut sama dengan MLT JHT dalam PP Penyelenggaraan Program JHT. Meskipun persyaratan untuk mendapatkan pembiayaan tersebut berbeda antara kedua program tersebut. Ketiga, ketidakjelasan status hukum BP Tapera. Baik UU Tapera maupun PP Tapera tidak menyebutkan atau menjelaskan status hukum BP Tapera. Untuk itu status hukum BP Tapera perlu

40 ibid., h. 2. dipertegas apakah badan hukum publik, BUMN atau privat. $^{41}$

Penerapan program Tapera tersebut dalam tataran norma dan implementasi ternyata belum atau tidak memberikan kepastian, keadilan, dan kemanfaatan bagi rakyat sebagaimana tujuan hukum menurut Gustav Radbruch. Permasalahan penerapan PP Tapera dalam pandangan Satjipto Rahardjo belum sesuai dengan Teori Hukum Progresif yang dikemukakannya yang muncul karena keprihatinan terhadap keadaan hukum di Indonesia. Keadaan hukum itu secara makro disebutnya tidak kunjung mendekati keadaan ideal, yaitu mensejahterakan dan membahagiakan rakyatnya. ${ }^{42}$ Untuk mendapatkan tujuan hukum yang maksimal menurut Satjipto Rahardjo dibangun dengan istilah Hukum Progresif, yaitu yang digantungkan kepada kemampuan manusia dalam menalar serta memahami dan nurani manusia untuk membuat interpretasi hukum yang mengutamakan nilai moral keadilan pada masyarakat. ${ }^{43}$ Di samping itu ide lainnya adalah hukum harus pro rakyat, pro keadilan, bertujuan untuk kesejahteraan dan kebahagiaan, berdasarkan kepada kehidupan yang baik, bersifat responsif, mendukung pembentukan negara hukum yang berhati nurani, dijalankan dengan kecerdasan spiritual serta bersifat membebaskan. ${ }^{44}$

Menurut Satjipto Rahardjo, penegakan hukum progresif adalah menjalankan hukum tidak hanya sekedar kata-kata hitam-putih dari peraturan (according to the letter), melainkan menurut semangat dan makna lebih dalam (to very meaning) dari undang-undang atau hukum dalam arti luas. Penegakan hukum tidak hanya kecerdasan intelektual, melainkan dengan kecerdasan spiritual. Dengan kata lain, penegakan hukum yang dilakukan dengan penuh determinasi, empati, dedikasi, komitmen terhadap penderitaan bangsa dan disertai keberanian untuk mencari jalan lain daripada yang biasa dilakukan. ${ }^{45}$ Ada beberapa

\footnotetext{
41 ibid., h. 4-5.
}

42 Satjipto Rahardjo. (2006). Membedah Hukum Progresif. Jakarta: Penerbit Buku Kompas, h. 9-10.

${ }^{43}$ H. Deni Nuryadi. (2016). "Teori Hukum Progresif dan Penerapannya di Indonesia". Jurnal Ilmiah Hukum De Jure: Kajian Ilmiah Hukum. 1 (2), h. 403.

44 ibid., h. 401.

45 Satjipto Rahardjo. (2009). Penegakan Hukum Suatu Tinjauan Sosiologis. Yogyakarta: Genta Publishing, h. 13. 
Neysa Tania, Jason Novienco dan Dixon Sanjaya, Kajian Teori Hukum Progresif terhadap Implementasi Produk Tabungan Perumahan Rakyat

kata kunci yang layak untuk diperhatikan tatkala kita ingin mengangkat pengertian progresivisme, yaitu: ${ }^{46}$ a. Hukum mengikuti perkembangan aspirasi masyarakat (hukum digantungkan kepada situasi dan kondisi kebutuhan pengaturan masyarakat); $b$. Hukum harus memihak kepada kepentingan Rakyat dan demi kepentingan Keadilan; c. Hukum bertujuan mengantarkan manusia kepada kesejahteraan dan kebahagian; d. Hukum selalu bergerak dalam proses perubahan (law as a process, law in the making); e. Hukum menekankan kehidupan yang lebih baik sebagai dasar hukum yang baik; f. Hukumnya memiliki tipe responsif; g. Hukum mendorong peran publik; h. Hukum membangun negara hukum yang berhati nurani.

Dikatakan bahwa hukum progresif merupakan hukum yang mengikuti perkembangan aspirasi masyarakat, namun dalam penerapan PP Tapera ini banyak masyarakat yang menolak, tidak hanya golongan pekerja tetapi juga pengusaha dan juga beberapa Anggota Komisi DPR RI. Dengan tetap diterapkannya PP Tapera pemerintah tidak memegang teguh prinsip hukum progresif. Selain itu dikatakan juga bahwa hukum harus memihak kepada kepentingan rakyat dan demi kepentingan keadilan, dengan adanya iuran tambahan kepada masyarakat di tengah kondisi ekonomi dunia yang stagnan, PP Tapera ini terlihat lebih condong membebankan biaya iuran kepada masyarakat dan memihak kepada kepentingan pemerintah untuk mengurangi defisit anggaran selama pandemi Covid-19 sebagaimana dalam Pasal 27 PP Tapera menyatakan bahwa dana dapat diinvestasikan ke Surat Utang Pemerintah Pusat dan Daerah. Hal ini sangat bertolak belakang dengan tujuan dari hukum progresif yang diharapkan oleh Satjipto Rahardjo.

Semangat dan jiwa dari Hukum Progresif, yaitu untuk memberikan keadilan dan memberikan kebahagiaan kepada masyarakat adalah sejalan dengan tujuan pembentukan pemerintahan Indonesia yang disebutkan dalam Pembukaan UUD 1945 dengan butir-butir Pancasila, sebagai falsafah bangsa dan batang tubuh UUD 1945 sebagai cita hukum dan landasan hukum dalam berbangsa dan bernegara: ${ }^{47}$

\footnotetext{
${ }^{46}$ Ahmad Muliadi. (2012). Makalah Politik Hukum. Jakarta: SAP S2 Universitas Jayabaya, h. 16.

${ }^{47}$ H. Deni Nuryadi. op.cit., h. 404-405.
}

Pertama, Dalam alinea keempat Pembukaan UUD 1945 disebutkan tujuan pembentukan pemerintahan Indonesia “(...) untuk membentuk suatu pemerintahan negara Indonesia yang melindungi segenap bangsa Indonesia (...)." Frasa ini mengamanatkan kepada Pemerintah untuk memberikan perlindungan kepada segenap bangsa Indonesia tanpa kecuali. Tujuan yang hendak dicapai oleh Pemerintah adalah sejalan dengan tujuan Hukum Progresif untuk memberikan keadilan dan kebahagiaan kepada masyarakat.

Kedua, Pancasila, sila kedua "Kemanusiaan yang adil dan beradab" dan sila kelima "Keadilan sosial bagi seluruh rakyat Indonesia". Sesuai dengan yang hendak dituju oleh Hukum Progresif yaitu memberikan keadilan kepada masyarakat.

Ketiga, Pasal 24 ayat (1) UUD 1945 mengatur "Kekuasaan kehakiman adalah kekuasaan yang merdeka untuk menyelenggarakan peradilan guna menegakkan hukum dan keadilan". Pasal ini menjamin bahwa hakim mempunyai kemerdekaan atau kebebasan yang tidak boleh diintervensi oleh pihak manapun untuk memberikan keadilan sesuai dengan keyakinannya yang didasarkan kepada kematangan intelektual dan hati nuraninya. Perilaku hakim seperti inilah yang diperlukan untuk menggerakan roda Hukum Progresif.

Keempat, Pasal 27 ayat (1) UUD 1945 mengatur mengenai persamaan kedudukan di dalam hukum untuk semua warga negara Indonesia. Dengan pasal ini semua warga negara mendapatkan perlakuan hukum yang sama meski memiliki latar belakang yang berbeda. Pasal ini akan mengantar seorang hakim untuk memberikan putusan hukum yang memberikan rasa keadilan kepada pemohon keadilan yang adalah sesuatu yang didambakan dalam Hukum Progresif.

Kelima, Pasal-pasal yang termuat dalam Bab XA mengenai Hak Asasi Manusia adalah mengatur hakhak dasar manusia. Hukum memberikan kewajiban kepada pemerintah untuk memberikan hak-hak yang membahagiakan rakyat, sesuatu yang menjadi tujuan dari Hukum Progresif.

Dalam hal ini UU Tapera memang dibentuk dengan tujuan untuk mengantarkan manusia kepada kesejahteraan dan kebahagiaan. Konfederasi Serikat Pekerja Indonesia (KSPI) juga menilai positif mengenai program Tabungan Perumahan Rakyat. Hal tersebut lantaran program tersebut sangat positif 
untuk kaum buruh dan masyarakat, agar mereka memiliki kesempatan untuk bisa memiliki rumah. ${ }^{48}$ Adapun pemanfaatan atas dana Tapera terdiri dari 2 jenis, yaitu hak pemanfaatan untuk pembiayaan perumahan serta hak memperoleh pengembalian simpanan dan hasil pemumpukannya. Pertama, pemanfaatan dana Tapera untuk rumah adalah khusus peserta kategori MBR dengan KPR 5\% flat sepanjang tenor pinjaman dan dapat digunakan untuk pemilikan, pembangunan rumah baru, atau perbaikan rumah. Kedua, pengembalian simpanan dan hasil pemupukannya untuk seluruh peserta termasuk yang sudah memanfaatkan pembiayaan perumahan dengan bunga simpanan yang dikembalikan $(2.5 \%-3 \%$ dari total simpanan). ${ }^{49}$

Masalahnya di masa pandemi Covid-19, daya beli masyarakat terhadap kebutuhan hidup cenderung menurun dan ketergantungan masyarakat terhadap bantuan sosial untuk menyokong kebutuhan seharihari masih tinggi dan akan menambah beban hidup masyarakat apabila masyarakat peserta Tapera kategori pekerja dan pekerja mandiri harus menyisihkan sebagian dari gaji atau upah yang cenderung menurun tersebut untuk membayar simpanan peserta tabungan perumahan rakyat. Pengaturan mengenai peserta tabungan perumahan rakyat ini berlaku untuk setiap pekerja dan yang berprofesi dalam bidang usaha apapun tanpa terkecuali, yang berpenghasilan setidak-tidaknya upah minimum, maupun pekerja atau pekerja mandiri yang berpenghasilan di bawah upah minimum yang ingin mengikuti Program Tabungan Perumahan Rakyat sebagaimana ditegaskan dalam Pasal 7 PP Tapera.

\section{PENUTUP}

\section{Kesimpulan}

Pembentukan PP Tapera sejatinya belum sejalan dengan ketentuan dalam UU Nomor 12 Tahun 2011 yang menjadi pedoman pembentukan peraturan

\footnotetext{
${ }^{48}$ Ratih Waseso. "Dukung Tapera, KSPI minta PP Nomor 25 Tahun 2020 Dibenahi”. https://nasional. kontan.co.id/news/ dukung-tapera-kspi-minta-pp-nomor-25-tahun-2020-dibenahi. diakses pada tanggal 16 Februari 2021.

${ }^{49}$ Direktorat Jenderal Pembiayaan Perumahan Kementerian Pekerjaan Umum dan Perumahan Rakyat. Tabungan Perumahan Rakyat. Diseminasi NSPK Pembiayaan Perumahan Di Wilayah I di Provinsi Sumatera Utara. http://pembiayaan.pu.go.id/ datamining/ckfinder/us erfiles/files/TAPERA.pdf. Diakses pada 20 Maret 2021.
}

perundang-undangan, hal ini dikarenakan masih terdapat cacat formil dan materiil. Pembentukan regulasi tersebut dinilai tidak taat asas pembentukan peraturan perundangan-undangan khususnya asas dapat dilaksanakan, asas keterbukaan, asas kedayagunaan dan kehasilgunaan, dan juga tidak memberikan kepastian hukum karena PP Tapera dikeluarkan 2 (dua) tahun lebih dari jangka waktu yang ditetapkan dalam UU Tapera.

Penerapan PP Tapera di tengah masa pandemi Covid-19 dinilai tidak tepat. Teori hukum progresif mengharuskan hukum untuk mengikuti perkembangan aspirasi masyarakat, sedangkan banyak masyarakat yang menolak adanya tambahan pengumpulan iuran wajib bagi pekerja dan pengusaha sebagai peserta dari PP Tapera ini. Di samping itu, turunnya daya beli masyarakat selama pandemi Covid-19 dan ketergantungan masyarakat yang cukup tinggi terhadap bantuan sosial untuk menyokong kebutuhan sehari-hari justru akan menghambat penerapan PP Tapera dalam memberikan dampak yang positif bagi kesejahteraan dan kebahagiaan masyarakat sesuai dengan tujuan hukum progresif.

\section{Rekomendasi}

Pemerintah sebaiknya menunda terlebih dahulu penerbitan PP Tapera dengan merevisi kebijakan hukum yang termuat dalam PP dan memberikan relaksasi terhadap kewajiban membayar iuran wajib bagi peserta program Tabungan Perumahan Rakyat di masa pandemi Covid-19 sehingga program ini menjadi alat yang bermanfaat untuk mendorong kesejahteraan masyarakat untuk mendapatkan hunian yang layak. Pemerintah juga perlu melakukan sosialisasi dan penyuluhan secara massif kepada berbagai lapisan masyarakat mengenai eksistensi Program Tabungan Perumahan Rakyat termasuk manfaat yang diperoleh bagi masyarakat sehingga terbangun kesadaran hukum bagi masyarakat untuk dapat berpartisipasi dalam program tersebut.

\section{DAFTAR PUSTAKA}

\section{Peraturan Perundang-undangan:}

Undang-Undang Dasar Negara Republik Indonesia Tahun 1945.

Undang-Undang Nomor 39 Tahun 1999 tentang Hak Asasi Manusia. 
Neysa Tania, Jason Novienco dan Dixon Sanjaya, Kajian Teori Hukum Progresif terhadap Implementasi Produk Tabungan Perumahan Rakyat

Undang-Undang Nomor 40 Tahun 2004 tentang Sistem Jaminan Nasional.

Undang-Undang Nomor 1 Tahun 2011 tentang Perumahan dan Kawasan Permukiman.

Undang-Undang Nomor 12 Tahun 2011 tentang Pembentukan Peraturan Perundang-undangan.

Undang-Undang Nomor 30 Tahun 2014 tentang Administrasi Pemerintahan.

Undang-Undang Nomor 46 Tahun 2015 tentang Penyelenggaraan Program Jaminan Hari Tua.

Undang-Undang Nomor 4 Tahun 2016 tentang Tabungan Perumahan Rakyat.

International Convenant on Civil and Political Rights.

Peraturan Pemerintah Nomor 25 Tahun 2020 tentang Penyelenggaraan Tabungan Perumahan Rakyat.

\section{Buku:}

Ahmad Muliadi. (2012). Makalah Politik Hukum. Jakarta: SAP S2 Universitas Jayabaya.

Bagir Manan. (1996). Politik Perundang-undangan Dalam Rangka Mengantisipasi Liberalisme Perekonomian. Bandar Lampung: FH UNLA.

Budi Prayitno, dkk. (2012). Kesejahteraan Rakyat Atas Papan: Akselerasi Pemenuhan Papan Bagi Peningkatan Kesejahteraan Rakyat. Jakarta: Kementerian Koordinator Bidang Kesejahteraan Rakyat Republik Indonesia.

C.G. Howard \& R. S. Mumners. (2010). Law: Its Nature and Limits. dalam Achmad Ali. Menguak Teori Hukum (Legal Theory) \& Teori Peradilan (Judicialprudence) Termasuk Undang-Undang (Legisprudence): Volume I Pemahaman Awal. Jakarta: Kencana Prenada Media Group.

Darmawan Triwibowo dan Sugeng Bahagijo. (2006). Mimpi Negara Kesejahteraan. Jakarta: Pustaka LP3S Indonesia.

H. Salim H.S. dan Erlies Septiana Nurbani. (2013). Penerapan Teori Hukum Pada Penelitian Tesis dan Disertasi. Jakarta: Raja Grafindo.

Hans Kelsen, diterjemahkan oleh Anders Wedberg. (2011). General Theory of Law and State. Clark, N.J.: The Lawbook Exchange.

Hans Nawiasky. (1941). Allgemeine Rechtslehre Als System Der Rechtlichen Grundbegriffe. Einsiedeln Etc: Benziger.
J.J. H. Bruggink diterjemahkan oleh Arief Sidharta. (1999). Refleksi tentang Hukum. Bandung: Citra Aditya Bakti.

Mukti Fajar dan Yulianto Achmad. (2017). Dualisme Penelitian Hukum Normatif dan Empiris. Cetakan IV. Yogyakarta: Pustaka Pelajar.

Philipus M. Hardjon dan Tatiek Sri Djamiati. (2020). Argumentasi Hukum. Cet. Ke-4. Yogyakarta: UGM Press.

Roni Hanitijo Soemitro. (1994). Metode Penelitian Hukum dan Jurimetri. Jakarta: Ghalia Indonesia. Satjipto Rahardjo, dikutip dari Ahmad Redi. (2018). Hukum Pembentukan Peraturan Perundangundangan. Jakarta: Sinar Grafika. . (2006). Membedah Hukum Progresif. Jakarta: Penerbit Buku Kompas. . (2009). Hukum dan Perilaku. Jakarta: Kompas.

. (2009). Hukum Progresif: Sebuah Sintesa Hukum Indonesia. Yogyakarta: Genta Publishing. . (2009). Penegakan Hukum Suatu Tinjauan Sosiologis. Yogyakarta: Genta Publishing. . (2010). Penegakan Hukum Progresif. Jakarta: Kompas.

Soerjono Soekanto dan Sri Mamudji. (2001). Penelitian Hukum Normatif Suatu Tinjauan Singkat. Jakarta: Rajawali Press.

Soerjono Soekanto. (1983). Penegakan Hukum. Bandung: Bina Cipta. (2007). Pengantar Penelitian Hukum. Jakarta: UI PRESS. . (2008). Faktor-Faktor Yang Mempengaruhi Penegakan Hukum. Jakarta: PT Raja Grafindo Persada.

Suharno. (2010). Dasar-Dasar Kebijakan Publik. Yogyakarta: UNY Press.

\section{Jurnal:}

Dewi Wuryandani. (2020). "Dampak Pandemi Covid-19 Terhadap Pertumbuhan Ekonomi Indonesia 2020 dan Solusinya". Info Singkat Bidang Ekonomi dan Kebijakan Publik. XII (15), h. 19-20.

Direktorat Jenderal Cipta Karya Kementerian Pekerjaan Umum dan Perumahan Rakyat. "Lembaran Baru Penuntasan Kawasan Permukiman Kumuh". Buletin Cipta Karya. Edisi 12. Tahun XII. Desember 2014, h. 8. 
H. Deni Nuryadi. (2016). "Teori Hukum Progresif dan Penerapannya di Indonesia”. Jurnal Ilmiah Hukum De Jure: Kajian Ilmiah Hukum. 1 (2).

Hyronimus Rhiti. (2016). "Landasan Filosofis Hukum Progresif". Jurnal Justitia Et Pax. 32 (1), h. 37.

Novianti. (2020). “Implikasi PP Penyelenggaraan Tapera dan PP Penyelenggaraan Program JHT Terhadap Program Perumahan Bagi Pekerja Swasta". Info Singkat Bidang Hukum. XII (12).

Sholihah Imas. (2016). "Polemik Undang-Undang Nomor 4 Tahun 2016 tentang Tabungan Perumahan Rakyat (TAPERA)". Jurnal Rechts Vinding Online. Media Pembinaan Hukum Nasional. ISSN 2089-9009.

Sidharta. Satjipto Raharjo dan Hukum Progresif Urgensi dan Kritik, dalam Any Farida. (2016). "Teori Hukum Pancasila Sebagai Sintesa Konvergensi Teori-Teori Hukum Indonesia". Jurnal Perspektif. XXI (1), h. 65.

Supriyadi. (2015). "Penetapan Tindak Pidana Sebagai Kejahatan dan Pelanggaran Dalam UndangUndang Pidana Khusus”. Jurnal Mimbar 27 (3).

\section{Disertasi/Makalah/Artikel:}

Adang Sutara. "Tabungan Perumahan Rakyat (TAPERA)". Makalah disampaikan dalam Seri Webinar PERKIM ke-10. 23 Juli 2020.

\section{Website:}

Ade Miranti Karunia. (16 Juni 2020). "Pemerintah Klaim Terbitnya PP Tapera Melalui Proses yang Panjang." https://money.kompas.com/ read/2020/06/16/204200126/pemerintahklaim-terbitnya-pp-tapera-melalui-proses-yangpanjang. Diakses pada tanggal 17 Maret 2021.
Adhi Wicaksono. "Kawasan Kumuh Indonesia Meluas Dua Kali Lipat". Dalam CNN Indonesia. 4 September 2019. https://www.cnnindonesia. com/nasional/20190903212554-20-427289/ kawasan-kumuh-indon esia-meluas-dua-kalilipat. Diakses pada 22 Februari 2021.

Direktorat Jenderal Pembiayaan Perumahan Kementerian Pekerjaan Umum dan Perumahan Rakyat. "Tabungan Perumahan Rakyat". Diseminasi NSPK Pembiayaan Perumahan Di Wilayah I di Provinsi Sumatera Utara. http:// pembiayaan.pu.go.id/datamining/ckfinder/us erfiles/files/TAPERA.pdf. diakses pada 20 Maret 2021.

CNN Indonesia. "Pekerja Dirumahkan dan Kena PHK Akibat Corona Capai 3,05 Juta". https://www.cnnindonesia.com/ekon omi/20200720114203-92-526610/pekerjadirumahkan-dan-kena-phk-akibat -coronacapai-305-juta. diakses pada 23 Februari 2021.

Ratih Waseso. "Dukung Tapera, KSPI minta PP Nomor 25 Tahun 2020 Dibenahi". https:// nasional. kontan.co.id/news/dukung-taperakspi-minta-pp-nomor-25-tahun-2020-dibenahi. diakses pada tanggal 16 Februari 2021.

Rofiq Hidayat. "Sejumlah Usulan Agar Pemerintah Merevisi PP Tapera." https://www.hukumonline. com /berita/baca/lt5ed87f8ac6144/sejumlahusulan-agar-pemerintah-merevisi-pp-tapera. Diakses pada tanggal 17 Maret 2021.

Dewan Perwakilan Rakyat Republik Indonesia, "Legislator Pertanyakan Penerbitan PP Tapera di Tengah Pandemi". https://www.dpr.go.id/ berita/detail/id/28949/t/Legislator+Pertanyakan + Penerbitan+PP+Tapera+di+Tengah+Pandemi, diakses pada tanggal 23 Februari 2021. 